\title{
Clumber Spaniel
}

National Cancer Institute

\section{Source}

National Cancer Institute. Clumber Spaniel. NCI Thesaurus. Code C53881.

The Clumber Spaniel is a massive dog with a broad, deep chest. It has a broad square head, with short, straight and strong-boned limbs. Its hair is thick and straight. Coat color is predominantly white, with either lemon or orange markings. Height: 16-20 inches (41$51 \mathrm{~cm}$.) Weight: 55-85 pounds (25-39 kg.) 